\title{
Absence of immunological hypersensitivity to dietary cow's-milk proteins in infant rabbits
}

\author{
By P. J. KILSHAW, M. J. HENSCHEL AND M. E. COATES \\ National Institute for Research in Dairying, Shinfield, Reading RG2 $9 A T$
}

(Received I3 February 1978 - Accepted 21 February 1978)

\begin{abstract}
I. Rabbits hand-reared on a diet based on cow's milk frequently experience convulsive and sometimes fatal reactions to their feed. These have been thought to be caused by immunological hypersensitivity to cow's milk.

2. This explanation has been re-examined and found to be untenable.
\end{abstract}

Germ-free rabbits hand-reared on semi-synthetic diets are subject to high mortality (Pleasants, Wostmann \& Zimmerman, I964; Stěpánková, Klepalová \& Kruml, 1972; Henschel, 1973; Dabard, 1976). Deaths before weaning have usually been attributed to dietary deficiencies, inhalation of food into the lungs or to inefficient protein digestion during the first week of life caused by reduced levels of pancreatic protease. Coates \& O'Donoghue (I967) observed that germ-free and conventional infant rabbits hand-reared on a liquid diet based on cow's milk frequently experienced sudden respiratory distress and convulsive spasms immediately after a feed, sometimes resulting in death. The outward similarity of this syndrome to systemic anaphylaxis (Movat, Uriuhara, Taichman, Rowsell \& Mustard, 1968) and the presence of degranulated basophils in the blood vessels of the mesentery led these workers to conclude that an immunological hypersensitivity reaction to cow's-milk proteins was responsible for the symptoms. This explanation has also been proposed by Henschel \& Coates (1974). Such a reaction, if substantiated, would be of considerable value as an experimental animal model of food allergy with particular relevance to the problem of cow'smilk intolerance in the human infant.

In the present report the immunological explanation for these reactions has been reexamined and found to be untenable.

\section{EXPERIMENTAL}

Rabbits

To eliminate complications arising from the enteric infections that frequently afflict infant rabbits hand-reared in a conventional environment the experiments described here were conducted in germ-free animals.

Infant New Zealand White rabbits were delivered by hysterectomy into Gustafsson germfree isolators 30-3I d post-coitus. They were hand-fed twice daily with a heat-sterilized liquid diet based on cow's milk (Henschel, 1973) using a small feeding bottle equipped with a latex teat. Weekly blood samples $(\mathrm{I} \cdot \mathrm{O} \mathrm{ml})$ were removed by cardiac puncture until the animals were weaned ( $2 \mathrm{I}-27 \mathrm{~d}$ after delivery); serum was recovered and stored at $-20^{\circ}$.

\section{Serological tests}

Passive haemagglutination tests were performed on forty-nine serum samples by the method of Stavitsky (I954) using sheep erythrocytes coated with cow's-milk casein or whey proteins.

Passive cutaneous anaphylaxis (PCA) tests were conducted on forty-four serum samples. 


\section{Table I. Incidence of deaths and 'shock' reactions to hand-feeding in germ-free infant rabbits}

(Mean values; values for percentage of total no. of rabbits in parentheses)

$\begin{array}{ccccc}\text { Rabbits delivered } & \begin{array}{c}\text { No. reacting } \\ \text { to feed }\end{array} & \begin{array}{c}\text { Total no. } \\ \text { reactions }\end{array} & \text { Feeding reactions } & \text { Other causes } \\ \text { I30 } & 42 & 157 & 14 & 37 \\ & (32) & & \text { (II) } & (28)\end{array}$

Undiluted serum (0. I ml) was injected intradermally into the shaved backs of 6-12-monthold New Zealand White males. After an interval of $72 \mathrm{~h}$ or $22 \mathrm{~h}$ the recipients were injected intravenously (i.v.) with $\mathrm{I} \cdot 0 \mathrm{ml}$ Evans blue $(50 \mathrm{~g} / \mathrm{l}$ ) accompanied by either $\mathrm{I}-2 \mathrm{ml}$ infant rabbit diet or $40 \mathrm{mg}$ casein and $40 \mathrm{mg}$ whey proteins. After $30 \mathrm{~min}$ the skin was examined for the presence of blue dye at the injection sites indicating a positive reaction. Latent periods of $72 \mathrm{~h}$ and $22 \mathrm{~h}$ were employed for optimal detection of $\mathrm{IgE}$ and IgGa antibodies respectively (Stux \& Ovary, 1976). Heterologous PCA tests to detect IgG antibodies were performed in guinea-pigs by a similar method; in this instance six sera were tested and recipients were challenged after a latent period of $5 \mathrm{~h}$ with $10 \mathrm{mg}$ casein and $10 \mathrm{mg}$ whey proteins in $0.5 \mathrm{ml}$ Evans blue ( $50 \mathrm{~g} / \mathrm{l})$.

Seventeen serum samples were tested for precipitating antibodies by double diffusion in agar gel ( $10 \mathrm{~g} / \mathrm{l})$ using sodium caseinate or whey proteins as antigens, both at $2 \mathrm{mg} / \mathrm{ml}$.

The validity of all serological tests was ascertained by including rabbit anti-whole cow's milk or anti- $\beta$-lactoglobulin antisera of known titre as internal standards.

\section{Intratracheal injections}

Infant rabbits were removed from germ-free isolators $22 \mathrm{~d}$ after delivery and $0.2 \mathrm{ml}$ of their diet was injected directly into the trachea without anaesthesia.

\section{Haematological investigations}

Blood samples were removed immediately before and after typical 'shock' reactions to a feed and basophils were stained and counted essentially according to the method of Meng, Pinckard \& Halonen (1973). Blood platelet counts were performed by phase-contrast microscopy on blood diluted $\mathrm{I}: 100$ with normal saline ( $9 \mathrm{~g}$ sodium chloride/l) or ammonium oxalate $(\mathrm{I} / \mathrm{g} / \mathrm{l})$ contained within a platelet counting chamber with Neubauer ruling.

\section{Histology}

Specimens of gut mesentery and omentum were removed from three germ-free rabbits immediately after a reaction to their feed and from two germ-free control animals which had shown no symptoms. The tissues were prepared as spreads, fixed with ethanol $(800 \mathrm{ml} / \mathrm{l})$ and stained with aqueous toluidine blue ( $10 \mathrm{~g} / \mathrm{l}$ ).

Lung tissue was removed from one rabbit after a fatal reaction to its feed and was fixed in formol-saline, sectioned and stained with haematoxylin and eosin.

\section{RESULTS}

Table I shows the incidence of deaths and 'shock' reactions provoked by feeding among infant germ-free rabbits over a 2 year period of observation. Such reactions usually occurred within I-2 min of the rabbits taking the teat of the feeding bottle and varied in intensity from transient tachypnoea and weaving of the head to complete respiratory failure, con- 
vulsions, ataxia, paresis of the hind limbs and death. These symptoms did not occur in rabbits younger than $\mathrm{Io} d$ old.

Of the serum samples taken from some of these animals over the 3-4 week period before weaning none contained milk-specific antibodies detectable by precipitation, haemagglutination or PCA tests; $39 \%$ of the samples came from animals which had shown typical reactions to their feed.

Rabbit diet was injected into the trachea in eight germ-free rabbits and caused only slight discomfort; three of these animals had previously reacted to their feed. Similarly, another eight rabbits, two with a history of feeding reactions, were injected i.v. with Io mg milk proteins or $0.2 \mathrm{ml}$ of their diet diluted with saline ( $\mathrm{I}: \mathrm{r}, \mathrm{v} / \mathrm{v})$, again none showed distress.

In contrast to the results of Coates \& O'Donoghue (I967) histological examination of the gut mesentery and omentum failed to reveal any differences between rabbits which had or had not suffered 'shock' reactions.

Basophil counts on blood samples taken immediately before and after typical feeding reactions were conducted in five germ-free rabbits. A mean reduction of $9 \%$ (SD I 8 ) was observed in counts taken after the reactions. This difference is not significant. Similarly, counts of platelets and total leucocytes in two of these animals showed no significant changes.

Microscopic examination of the lungs of a rabbit that had died during a feeding reaction revealed extensive haemorrhage and partial collapse. Some bronchioles were blocked and infiltrated with polymorphs. There was no evidence of obstruction of the pulmonary vasculature.

\section{DISCUSSION}

Systemic anaphylaxis in the rabbit has been reported to occur after i.v. injection of antigen into animals which contain high titres of precipitating antibodies in their circulation. The reaction results from occlusion of the pulmonary capillaries by aggregates consisting of antigen-antibody precipitates, platelets and polymorphs and is accompanied by profound thrombocytopenia and leucocytopenia (Movat et al. 1968). Soluble immune complexes too, if introduced into the circulation, will cause shock or death, possibly resulting from constriction of the pulmonary artery (Weigle, Cochrane \& Dixon, 1960). Antigen injected i.v. into rabbits which are synthesizing only IgE antibodies can also cause anaphylaxis (Pinckard, Halonen \& Meng, 1972). In this instance a number of haematological changes are to be found including a rapid depletion of basophils (Halonen \& Pinckard, 1975), but the reaction is not considered to occur in infant rabbits because of their transient insensitivity to some pharmacological mediators (Meng et al. 1973). The lack of detectable antibodies in our germ-free rabbits and the absence of haematological changes argue against a role for any of these mechanisms in the feeding reactions we describe. Whilst it is quite conceivable that milk proteins could reach the circulation at the time of a feed by absorption through the gut or lungs our results indicate that they would not cause anaphylaxis. Indeed, i.v. injections of such material were well tolerated by our rabbits. Furthermore, the observation that small injections of diet into the trachea caused no ill-effects denies the existence of a local anaphylactic reaction in the lungs.

Mature rabbits given cow's milk in a conventional environment have been reported to produce milk-specific antibodies, although without evidence of hypersensitivity reactions (Rothberg \& Farr, 1965). It is possible that germ-free infant rabbits too would eventually respond in this way, although immunological tolerance would be a more likely outcome of neonatal exposure to antigens in the absence of an adjuvant (Pinckard et al. 1972; Filipp \& Boros, I967).

Histological examination of the lungs of a rabbit that had died while feeding showed that 
the pulmonary capillaries were unobstructed; this is further evidence that aggregate anaphylaxis had not taken place. There was however extensive haemorrhage and partial obstruction of the 'air-ways'. It is likely that part of this damage had been present for some days before death because an infiltrate of polymorphs was present both in and around the blocked bronchioles. Similar inflammatory reactions, thought to be caused by inhaled diet, have been described by Dabard (1976) and Štěpánková et al. (1972). Prominent haemorrhages have frequently been seen in the lungs of our rabbits regardless of whether or not they had experienced convulsive spasms; clearly, lung function in these animals was profoundly impaired.

Wealthall (1975) reported that nasal stimulation of infant rabbits with cold water or a tactile stimulus 5-30 d post-partum sometimes caused fatal apnoea. This reflex should be considered as a possible explanation for fatalities during artificial feeding, although we have so far been unable to reproduce the symptoms by introducing $0.1-0.15 \mathrm{ml}$ water or rabbit diet into the nostrils of doe-reared infant rabbits. The observations of ourselves and others suggest that during artificial feeding relatively large quantities of diet are inhaled, either directly from the feeding bottle or by regurgitation from the stomach. Although we cannot entirely exclude mechanical blockage of the 'air-ways' as the only cause of sudden death in our experiments, it is considered more likely that neurological mechanisms interfering with normal respiratory drive play an important part in the reaction. This hypothesis is at present under investigation.

The authors gratefully acknowledge the technical assistance of $\mathrm{Mr}$ J. P. Fordham and $\mathrm{Mr}$ D. A. F. Miles and the help of Mr A. Turvey with histology.

\section{REFERENCES}

Coates, M. E. \& O'Donoghue, P. N. (1967). Nature, Lond. 213, 307.

Dabard, J. (1976). Sci. Tech. Anim. Lab. r, 89.

Filipp, G. \& v.Boros, B. (1967). J. Allergy 39, 167.

Halonen, M. \& Pinckard, R. N. (I975). J. Immun. I15, 519.

Henschel, M. J. (1973). Br. J. Nutr. 30, 35I.

Henschel, M. J. \& Coates, M. E. (1974). Proc. Nutr. Soc. 33, I 12 A.

Meng, A. L., Pinckard, R. N. \& Halonen, M. (I973). J. Immun. x10, 1554.

Movat, H. Z., Uriuhara, T., Taichman, N. S., Roswell, H. C. \& Mustard, J. F. (I968). Immunology I4, 637.

Pinckard, R. N., Halonen, M. \& Meng, A. L. (1972). J. Allergy Clin. Immunol. 49, 301.

Pleasants, J. R., Wostmann, B. S. \& Zimmerman, D. R. (1964). Lab. Anim. Care 14, 37.

Rothberg, R. M. \& Farr, R. S. (1965). J. Allergy 36, 450.

Stavitsky, A. B. (1954). J. Immun. 72, 360.

Stěpánková, R., Klepalová, J. \& Kruml, J. (1972). Folia Microbiol., Praha 17, 505.

Stux, S. V. \& Ovary, Z. (1976). Int. Arch. Allerg'y appl. Immun. 51, 338.

Wealthall, S. R. (1975). In Development of Upper Respiratory Anatomy and Function. Implications for Sudden Infant Death Syndrome, p. 212 US Dept Hlth Welfare publ. no. (NIH) 75-94I.

Weigle, W. O., Cochrame, C. G. \& Dixon, F. J. (1960). J. Immun. 85, 469. 